\title{
Allan Baillie's Secrets of Walden Rising as Critical Dystopia: Problematising National Mythologies
}

\author{
Beverley Pennell
}

Allan Baillie's Secrets of Walden Rising (1996) is a novel about 'the politics of history' (Fernandez 2001, p. 42) and an examination of the text's significant challenges to the dominant historical stories of its time seems appropriate as Australia's 'history wars' continue. In this paper I examine the critical dystopian strategies employed in Secrets of Walden Rising to subvert some of the utopian national mythologies of white settler Australia. Baccolini (2003 p.115) argues that critical dystopias tend to be 'immediately rooted in history' and that the critique they carry out exposes the revisionist impulse of historical narratives and the erasures they inevitably sanction. In Secrets of Walden Rising the control of national narratives and its erasures are represented as the underside of utopian national mythologies. In this text, the dystopian discourse opposes the pursuit of agricultural profits where this requires a disregard for the sustainability of the natural landscape, critiquing the pursuit of profit when it depends upon violence and social hierarchies for its continuation. The critical dystopian conventions of the novel set up a dialogue between past and present society, between the contemporary dystopian experience of a despoiled rural Australia and the older national mythologies that construct utopian versions of 'Australia' as either a pastoral idyll, or as an exciting frontier gold-mining town where fortunes are made, or as a working man's paradise. Secrets of Walden Rising is apocryphal in its closure, offering a caution for the present time with regard to environmental sustainability in the face of a society where economic imperatives remain central to its raison d'être. Baccolini and Moylan (2003, p.7) argue that traditional dystopias 'maintain utopian hope outside their pages, if at all; for it is only if we consider dystopia as a warning that we as readers can hope to escape its pessimistic future'. However in the critical dystopia, Baccolini and Moylan (2003, p.7) argue that hope is offered within the text. Secrets of Walden Rising is bleak in closure and the cognitive engagement outside the reading of the text is part of its pleasure and pain. However insofar as the novel's closure invites readers to note the warning signs seen by the main protagonist, Brendan, the novel offers a 'horizon of hope' (Baccolini and Moylan 2003, p.6) within the text.
Secrets of Walden Rising has been discussed as an example of the 'boy's own adventure' novel (Fernandez 2001,p.42) in which the primary storyline constructs 'a kind of treasure hunt' (Stephens 1999, p.64). However, it is possible to read the novel as imploding the 'boy's own adventure' novel by its articulation and repudiation of the violence and lawlessness that are intrinsic to the adventure genre , its heroes' exploits and its imperialist ideologies. The novel employs Australian iconography that extends the significations of the novel beyond the adventure genre. Central to this is the metonymic functioning in the resurfacing of a fictional nineteenth-century gold-mining township, Walden. Walden is rising out of the waters of Lake Fedder, a man-made dam, in a season of severe drought, its repressed colonial stories producing a dialogue with dominant discourses in the present day township of Jacks Marsh. Spatio-temporal framing is foregrounded as is conventional in dystopias. As the newcomer in contemporary Jacks Marsh, Brendan observes the lake's rising from his hiding-place at the edge of the forest, at the same time critically assessing the stories told to him by the locals, concerning the past and present.

Richard White argues that the intention of national histories is to give 'a diverse contemporary society a common past' and confer on 'the geographical space a cultural unity' (1997, p.14). There are historical moments when national issues dominate public affairs and at such times the ideology and raison d'être of the 'nation' are sharply contested. Wegner (2002, p.xvii) argues that it is at such times of 'upheaval, contradiction and change' that the utopian form, and I argue that the dystopian form too, emerges as a powerful oppositional voice in a society. In Australia, the late 1980s and early 1990s was a period of contestation and rupture of many Australian national stories. White argues specifically that in Australia, the 1988 Bicentennial's theme of 'Celebration of the Nation' with its explicit postmodern 'gloss of multiple identities' reveals a 'tendency to leave out of the equation the contest for dominance. All multiple identities are seen as equal, when in fact some are more equal than others' (1997, p.18). Curthoys' feminist history delineates some of these contested issues: 
To historians these debates revealed the continuing strength of non-Aboriginal Australia's belief in stories of pioneering, settlement and rightful occupation of the land, with many still holding the view that invasion and dispossession had been justified because Aboriginal people did not use the land productively. At the same time, the Mabo debate also revealed the growing strength of an alternative historical understanding emphasising the impossibility of justifying invasion in these or any terms, and valuing rather than condemning Aboriginal societies.

(1997, pp.31-2)

Curthoys' comment encapsulates the oppositional nature of recent national stories constructed about Australia's history. Secrets of Walden Rising appears then at one of those historical 'transitional moments' (Moylan 1986, p.43) in Australian history and such moments are identified as typical of social contexts that give rise to significant utopian and dystopian texts. Secrets of Walden Rising reflects concerns about 'invasion and dispossession' of indigenous peoples and about claims of white settlers to 'rightful occupation of the land'.

The divergence among the fin de siècle national mythologies of the Australian nation contested by the main political parties can be gauged from the ideological shifts evident in the utopian 'social dreamings' and rhetoric when John Howard's Liberal government replaced Paul Keating's Labor Government in 1996. Keating's national narrative was multiculturalist and internationalist in focus, telling of 'a people who had triumphed over their tribulations and prejudices to embrace diversity and tolerance with an egalitarian generosity, enabling them to adapt to an open, globalised economy and engage with their Asian neighbours' and who had put behind them 'old-world errors and wrongs and lies' (cited in Macintyre 1997, pp.ix-x). This national mythology refers, at least in part, to the subjugation of the indigenous populations by the white settlers. Prime Minister, John Howard, who came to power in 1996, labelled Keating's narrative as the 'black armband' view of history, employing Geoffrey Blainey's (1994) trope. Howard re-circulated a post-war national mythology of Australia: 'a story of heroic achievement, of prosperity wrought from wilderness, of democratic innovation, of the fair go' (cited in Macintyre 1997, pp. ix-x). Secrets of Walden Rising engages with many aspects of the Australian historical narratives mentioned explicitly or implicitly in the national stories of Keating and Howard. The novel demonstrates some of the serious elisions in both storylines and undermines aspects of both stories. In Cameron, Lawless and Young's Investigating Australian History in the Twentieth Century, a history text book for Year 10 students, the writers explain that 'The arrival of the First Fleet in Sydney Harbour, for instance, can be seen from the ship or the shore; ...' (2000/2001, x). The view from the ship - of the British arrivals and the process of colonisation - has been the dominant paradigm for most of Australia's historical writing while the postmodern and postcolonial view from 'the shore' remains contentious. Secrets of Walden Rising narrativises these controversial historical issues and offers a re-reading of colonialist white settler narratives. The tension between the 'view from the ship or the shore' gives rise to the critical dystopian perspective of Secrets of Walden Rising.

As is conventional in dystopias the storyline of Secrets of Walden Rising begins in media res (Baccolini and Moylan 2003, p. 5) with Brendan, a contemporary British migrant who has been in living and attending school in Jacks Marsh for some months. Brendan, a latter day 'Pom' (p.4), suffers being mimicked and wears a badge of otherness in his sunburn (p.8). As the main focaliser of the novel, Brendan's view is the one that counts for readers because, as Vasram argues, 'it is the perception of the protagonist that the reader is asked to accept as valid' (2003, p.205). Vasram also suggests that the protagonist clarifies the dystopian dilemmas within the society for readers because it is the protagonist who 'attempts to answer the question "which world is this, and what place do I occupy within it?"' (2003, p.205). Brendan's defamiliarised gaze records the behaviour of the citizens of the society (pp.6, 26, 39, $43,46)$; moreover, he is an artist and 'carried the pad like a tourist carries a camera, just in case' (p.33). He critiques the social interactions of the inhabitants of Jacks Marsh; he draws its flora and fauna, records the landscape and notes the events in the lives of the people (pp.2-6). Jacks Marsh is 'a very small township, a blink in the barren land' 
(p.7). The dystopian text generally creates an alternative world; in Secrets of Walden Rising the estrangement that 'focuses on the given situation but in a displaced manner to create a fresh view, is identified as central to the subversive quality of the genre' (Moylan 1986, p.33). Brendan's story, an immigrant's story, offers an estranged view of the society and its landscape, re-presenting rural Australia as dystopic. The demise of traditional colonial rural Australia is depicted in the 'one-horse town' (p.11) of Jacks Marsh that Brendan feels is 'at the end of the world (p.2). It is now 'half a ghost town' in a despoiled and unproductive landscape (pp.10-11), a dystopic landscape. The hotel is symbolically named The Terminus because its present owner's view aligns with Brendan's, that the town is at 'The goddam end of everything' (p.33). Century-old sepia photographs of Walden's main street and the town's community leaders hang on the walls in The Terminus, but the railhead planned for Jacks Marsh, that the hotel was intended to service, was never built because Walden's gold ran out (p.12).

Metonymy is the most significant discursive strategy used in Secrets of Walden Rising for distancing readers from the dominant traditional point of view in national stories. While the local children, whom Brendan meets at school, hold the dominant view from 'the ship' (Lawless et al 2001, p.x), contained in the oral histories of their parents and grandparents, Brendan 'sees from the shore', literally, as he observes Walden, buried for decades beneath Lake Fedder, re-surface as the old town gradually reappears, little by little above the waterline. Metonymically then, for readers, the Australian nineteenth-century socio-cultural context is revivified as Walden reappears. Brendan, as an explorer, pursues historical knowledge in order to understand the tensions and conflicts of twentieth-century rural Australia schematised in the spatio-temporal frame of Jacks Marsh. He 'discovers', for instance, the secrets of late nineteenth-century pastoral Australia that necessitate family secrets and sustain local feuds (p.119). Brendan eventually understands that the 'shadow of Walden reached across the flat into Jacks Marsh' (p.72), rather 'as if everything here was dying as Walden came back to life' (p.77). Here the critical dystopian convention is evident as the past, and the presaged bleak future, impact upon the present. Brendan's first 'social dreamings' about Walden are exciting and are thus quite unlike his experiences in Jacks Marsh. Watching Walden emerge is thrilling, and this part of the storyline presents an 'education of desire' (Baccolini and Moylan 2003, p.11): for Brendan and the reader 'Walden was rising. Brendan pulled his pad out and began to draw what he had seen. His hand trembled slightly on the paper' (p. 36). He attempts to keep the knowledge of Walden's rising out of the dam to himself (p. 45) especially once he learns that it is a former gold town: 'Not just a town under the water, but it was a gold town. It was getting better and better' (p.39). Brendan, like colonial settlers before him, temporarily experiences the desire to take possession of the land and all it contains (pp.17,44) and, like those who dominate the small society of Jacks Marsh, he is reluctant to share it. Brendan imagines the frontier gold town like this:

Tents all over the place, wild shouting when gold is found, singing and dancing all night long. There'd be troopers, and coaches and bushrangers chasing each other in the hills and the diggers would sing about them. There's nothing to be frightened of here, Harry.

(p.46-7)

His imaginings of the life of goldmining town suggest the adventure genre, or television costume drama (p.158). These imaginings will later be ironised as the novel problematises all national mythologies of nineteenthcentury colonial society as it represents the underside of utopian imaginings.

Utopian 'social dreaming' and desire are often the motivation for migration to a new land and this is the case for Brendan and his father who have decided to leave behind sorrowful memories in England and settle in Australia. Brendan's Dad comes to the Australian outback lured by colonialist utopian narratives of wilderness, adventure, frontier conquest and new opportunities, and believes that 'We're going to make tractors roar, make Land Rovers purr! We're going bush. Drovers, mobs of cattle, sheep, rivers thick with fish ...' (p. 9). As he imagines the utopian landscape of a pastoral idyll, also invoked here is the national mythology of the 'working man's paradise'(White 1981,p.41), expressed in his belief that he will be 'his own boss, sniffing the country 
air' (p.12). Here 'Australia' is constructed as the New Eden and this national narrative has a 'teleological dynamic' for the immigrants who embrace it (White 1997, p.21). Unlike his father, Brendan's utopian imaginings of the new land have nothing to do with rural Australia. Brendan's images come from a post-World War II era of Australian national stories when new urban images of 'the Australia way of life' were invented (White 1981, pp.157, 162). In these images the outdoor life and leisure played an important part where beaches, sun and surf are predominant images (p. 9). Disappointment follows for Brendan and eventually for his father, who holds to his dream longer than Brendan despite the scarcity of business. Jacks Marsh is hostile and Walden transforms from utopia to dystopia, being labelled as a 'bad place' (p.72). The utopian 'education of desire' becomes the 'education of perception' that is central to dystopian narratives (Baccolini and Moylan 2003, p.11).

As a critical newcomer to the dystopic society, Brendan fairly quickly comes to value the place he has left behind and feel nostalgic about it (pp.10, 58-9). Brendan's distressing memories of England, of his 'monster', 'troll of Uxbridge' (p.51) are given to readers in flashbacks. The monster and troll are figments of the imagination - they are a child's horror story that impacts on the real world only once when a frightened boy runs onto the road: 'And the kids laugh and make jokes about the troll in the abandoned house for months and months. But nobody ever goes into the house' (p.55). The English 'troll' and 'monster' establish a contrast between the imaginary and the 'real ghosts' and 'monsters' that refuse submergence in Australian social life. These include characters like the unscrupulous, greedy Lean Wilson, owner of the Jacks Marsh hotel (p.39), or the symbolic green bird, the weathercock that dominates Walden township as it sits atop the Empire Hotel: 'Brendan looked at the green bird. That's what you're like. The troll of Walden. Bluff and myth' (p.55). The motif implies that the ghosts of the Australian frontier society represent real issues that impact on lived experience and the constructions and reconstructions of national stories. The secrets of the colonial past literally rise before Brendan's eyes with the re-surfacing of Walden (p.34). The primary storyline climaxes with Brendan's witnessing two murders when Brendan and his classmate Bago watch powerless as Lean
Wilson, motivated by greed for stolen bushrangers' loot, murders Old Harry (pp.154). Then Brendan watches as Bago decides not to save Lean Wilson from falling to his death (p.165). The Granite is a place that resonates symbolically in the spatial framing of the narrative as it is the site of the genocide of the local indigenous peoples. The 'reality' of historical events as memory is affirmed here by the novel as it proposes that however distant the historical issues may be, matters of injustice must be redressed and reparations made in an attempt to ameliorate their consequences.

In Secrets of Walden Rising representations of white settler society as a pastoral idyll are dismantled and the denial of John Howard's 'prosperity wrought from wilderness' is absolute in the environmentalist concerns of the novel. Indeed the novel shows that 'old-world errors and wrongs and lies' are the source of environmental problems besieging the land. The novel's titles allude to David Henry Thoreau's Walden, or, Life in the Woods (1854). Thoreau's Walden is the iconic, foundational North American example of nature writing. It represents an account of two years (1845-7) Thoreau spent living in rustic simplicity at Walden Pond. For Thoreau, Walden symbolises the time of the narrator's spiritual enlightenment, as the outcome of his experiences in the wilderness. The use of 'Walden' in the title of Secrets of Walden Rising is ironic, since Brendan's experiences are hellish rather than spiritually affirming; in contrast to Thoreau's narrator, Brendan is in a 'fractured world', and his critical gaze ironises the landscape's failure to appear anything like the promised utopia. Only the forested area around the dam offers pastoral sanctuary. In Secrets of Walden Rising the contemporary spatio-temporal framework of Jacks Marsh, the Australian outback, is represented as a drought-stricken, despoiled landscape: a dust bowl, ripped by the huge agricultural machines that Brendan's father imagined it would be his business to repair. To his chagrin, Brendan's father finds little farm machinery currently in use and when started up it is to dig trenches for burying animals that must be put down because of the drought (pp.44, 59).

As in Thoreau's Walden, where Walden Pond is significant, so in Secrets of Walden Rising the literary discourse is marked by tropes to do with water. This functions to further undermine national narratives that represent Australia as a 
pastoral idyll. The rivers around Jacks Marsh have stopped moving; they are '[p] oison water', not only because of the drought, but because of the algal blooms that infest them when fertilisers and insecticides continually pollute the rivers (p.26). The name 'Lake Fedder' implies something natural rather than what it actually is, namely a disruption to the natural landscape (p.16). The presence of the dam is another way that white occupation has interfered with the environment and redirected the uses of vital but limited water resources. Finally, there is the symbolic pouring rain, figured in the closure, a cliche that is resignified because the narrator says that the deluge cannot, in fact, wash away 'the sins of the fathers' (p.165).

The narrative structure of Secrets of Walden Rising is of interest, particularly the fact that the novel's storylines of the two places_-Jacks Marsh and Walden - are introduced as if unconnected. The opening storyline of Walden is written in a symbolic mode that intimates the rupture that will follow the re-emergence of the nineteenth-century landscape. The second storyline of Jacks Marsh is in the realist mode and introduces the twentieth-century concerns of the main participants. In the introduction to Walden (p.1), an effaced narrator describes an eerie and apparently secret cove, lying undisturbed in night silence, where the first parts of a mysterious green bird gradually break the surface of the otherwise still waters. This bird is later revealed to be the weathercock on the long-submerged roof of Walden's 'Empire Hotel', but it is some way into the narrative before Brendan works out what it is and so demystifies it for readers. The bird is both 'ghost' (p.21) and a reality, capable of 'silently destroying' much more than just 'the soft calm of the cove' (p. 20). Readers learn later that past attempts to destroy the green bird have been made, but have always failed (p.39). It remains a symbol of chaos that is important throughout the novel. The opening paragraph of the novel is a single sentence paragraph: 'In the deep night the cove was waiting' (p.1). Discursively, here, the personification of the cove ascribes it with agency. Socio-culturally, the word 'cove' is portentous in Australia's historical narratives: the first colonial settlement was at Sydney Cove, early agriculture begins at Farm Cove and then later there is the battleground of Anzac Cove at Gallipoli. The word 'waiting' is also significant, suggesting an authoritative permanence and patience. The fantastic secret cove remains Brendan's secret for quite some way into the story and at first it has utopian dimensions and Brendan calls it his 'Sanctuary' (p.13) as its forest is cool and its tranquillity heals his troubled spirit (p.17). Determining what the place is and its historical significance brings Brendan into contact with various members of the Jacks Marsh community.

The next episode shifts to the second storyline setting in a school playground where the boys' relationships are conflicted and hierarchical. The episode develops around the boys' examination of a picture that Brendan is sketching (p.2). This enables the episode to function as a discussion of the construction of cultural texts and also of how such texts may be read and interpreted differently. The reader sees that the point of view of the producer of a cultural text effects the meanings constructed in the text, and that different perspectives result in a different story. The discussion among the child participants - and the narrative's dialogue with the reader-concerns competencies and aesthetic preferences in the production, reading and interpretation of different representational modes: fantasy, realism, humour and symbolism. Brendan and the other children are in the playground of the iconic one-roomed outback Australian primary school "not much bigger than a garage' and 'sagging in the heat 'with all the windows panting open' (p.5). Brendan is sitting alone and drawing a grey and pink feathered galah on a branch of a eucalyptus tree, a bird that contrasts with the metallic green weathercock emerging from the water of the cove. The various interpretations of Brendan's sketch are a strategy for discussing issues of representation and re-presentation, involving controversy among the boys who gather around Brendan to look at what he has drawn. The episode is a mise en abyme that parallels the larger issues of the writing of national histories. Again the reader's attention is drawn to the idea that national narratives are carefully shaped stories that selectively remember and forget.

The first debate about the sketch occurs in an exchange between Brendan and Tony, who also admits to enjoying drawing. Tony challenges Brendan's realist drawings of the galahs as lacking in imagination, 'a bit dull' (p.2). Ironically the 'ugly bird' - 'hostile' and 'ready to explode 
into shrieking anger' - symbolises the dystopic aspects of Jacks Marsh for Brendan but he does not dare tell Tony this (p.3). To please Tony, Brendan alters his original sketch by making the bird appear fantastic. When two other boys - Bago and Elliot - join the discussion, the reader sees Bago's inability to give significance to anything that is not representational (p. 5). Bago ridicules the fantasy drawing of the galah with fangs, preferring Brendan's sketch of 'the grey school building with the old red gum behind it (p.5). The form and manner of representations and the differing reader receptions are thus significant issues in the text. Realist representations are assumed by some participants to be unmediated reflections of reality. Brendan is fully alert to the different readings his visual texts evoke; like newcomers in other dystopian novels, he is aware of the divergent viewpoints of citizens of the place he is exploring, and is able to resist those he finds repugnant. The novel is already suggesting through this mise en abyme the impossibility of a unitary history but also the pressures of those who hold power among the peer group to impose their views and oppose alternative ones.

White $(1981,1997)$ argues that Australian white settler history is often presented in terms of heroes, misunderstood villains, men of great vision and of awe-inspiring determination. In Secrets of Walden Rising the Cardiff family, wealthy local property owners in Jacks Marsh, see their family history as the story of men of vision and determination. The imperialist nature of their enterprise is signified in the novel by the name of the family's hotel in Walden, The Empire. Elliott Cardiff is a third generation local and says to Brendan, 'Walden is my town, Pom' and to his school peers in general: 'We were here first ... . This is our place' (p.41). Ironically, Brendan, like the colonial explorers and settlers of the past, experiences the temptation to exercise power and to take possession of land and property when he first walks the streets of the resurrected Walden (pp.91, 92-7). Brendan speaks to the portentous green weathercock: 'This is my town, bird. You can fly off' (92). Brendan does not even realise the name of the town at this stage, nor any of its histories. When he first hears a local use the word 'walden' he has no idea what it means and his best guess is that it is a bird (pp.31, 34). Later in the storyline, when Brendan learns about the different versions of Walden's history, he reflects as he studies the re-surfacing township:

He found a small rectangle low in the water near the ruined church, that must be the cheapjack, the ancestral property that Tony was so proud of. So Elliott's ancestor built the Empire at one end of the street and Tony's built at the other end and Bago's ancestor dug gold for them both. Harry's bushranger probably robbed them both. Still seems all right.

(p.55)

Brendan's ironic focalisation is partly the result of his resentment at how his peers marginalise him, but his perspective as a stranger in the society allows the recognition of the perpetuation of old values that continue to influence attitudes and behaviours. An 'education of perception' (Baccolini and Moylan 2003, p.11) occurs for Brendan as it does for the reader. Secrets of Walden Rising represents the colonial enterprise as economically motivated, with codes of greed and self-interest determining behaviour and overriding other values. The novel also undermines the legendary Australian masculine attribute of mateship, which is deconstructed as illusory in the light of the families' three generations of rivalries and hatreds that re-surface among the boys. Brendan sees verbal and physical violence erupt many times (pp.4, 6, 41-2, 61-2). Old Harry says of Walden that 'Sometimes it comes back' (p.67) and his non sequitur functions as a prolepsis and builds tension. In the climax of the novel Old Harry fights with Lean Wilson over bushranger's loot - 'Thunderbolt's treasure'-in the muddy streets of Walden. Old Harry cries, 'No! This is not yours, this is ours! Ours!' but Wilson's retort subverts the meaning of the treasure when he states that they are now only competing over the size of their gravestones (pp.1523 ). It is Brendan and Bago who are left to discover that the supposed treasure is worthless dust (p.165).

The bleakest dystopian aspect of Secrets of Walden Rising deals with the effacement of the stories of indigenous populations from white settler histories, addressing pressing issues of reconciliation. Baccolini and Moylan argue that 'Language is a key weapon for the reigning dystopian power structure' ((2003, pp.5-6), and here claims of terra nullius are essential to the Cardiff family's legitimacy as 
landowners, since the Cardiff forebears are implicated in the genocide of the local Aboriginal population. White (1981) argues of nineteenth-century colonial society that it exhibited the racism inherent in Social Darwinist ideology, which provided the intellectual underpinning for one dynamic of British imperialist ideology: 'As long as racial purity was maintained, as long as only the noblest racial strain was permitted to flourish in Australian soil, then the future of the Australian branch of the British race was secure' (White 1981, p.71). Elliott and his family must deny any claims of earlier occupation of the land by Aboriginal populations, and so he dismisses a stone spearhead found near Walden as just 'a rock' (p.67). Brendan's perspective of the local community is shaped by such diverse and contradictory views and in making his own judgement he understands the inevitability of a dystopian reading of Walden: 'Walden was not friendly now' (p.71). Brendan knows that 'The stories of Harry and Tony had changed Walden into a town of murder' with 'hills that were laced with forgotten bones' and 'the diggings where men were attacked with pick handles and torches ... a town of murder. That made the difference' (p.72). Brendan decides to stay away from the town (p. 80) but he cannot hold to his determination as the town haunts his dreams (p.83). The compelling economic imperative of profit - from agricultural and pastoral land and the discovery of ore and mineral deposits - is elided in white settler histories, 'the view from the ship', yet it underpins the continuing feud between the Cardiffs and Bago's family about land and water ownership (pp.66-7), with its continuing violence, lawlessness and shame that necessitates secrets and hypocrisy. The dystopian closure of the novel-discussed below-sees Bago take up the murderous traditions of his society (p.165).

Sambell (2003, pp.163-79) finds that children's dystopian novels often fall short of their appropriate endings by offering a rescue or means of escape for the child participant so that readers are given a hopeful outcome. Secrets of Walden Rising certainly avoids this pitfall. The discursive strategies employed in the closure of Secrets of Walden Rising signify the dangerous temptation to alter nothing and to perpetuate patriarchal and imperialist social structures and practices in Australian society. The emerging 'ghost' copper weathercock on the roof of Walden's hotel 'creaked over the water' and is 'shining' its warning loud and clear for Brendan, the stranger and explorer, who heeds its message. Bago does not even register its existence (pp.167-8) and his final line of dialogue suggests the unwillingness of subjects to read the signs. Bago's and Brendan's alliance operates only against the threat of Lean Wilson with his murderous intentions (pp.155-9). In the closure any further alliance between Brendan and Bago is problematised in a brief, disturbing dialogue where Bago reflects on the violence that he has been involved in, and comments that: 'It was easy. Like killing sheep' (p.168). His dialogue here functions as the traditional dystopian warning, and asserts the need to confront violence and to declare it as illegitimate as a means of social organisation. Implicit here is the idea that ignoring violence will in fact perpetuate it. Readers are positioned to decide between the implications of Brendan's understanding of the symbolic message of warning and Bago's sense of empowerment through violence as a means of control and domination. Bago's remark is then a significant dystopian marker since the newcomer to the society rejects such a moral void. The markers of dystopian society include corruption of youth, the triumph of 'old-world wrongs, errors and lies' and condoning of violence as a means to power.

Issues of governance are significant in dystopian narratives, typically representing dystopic societies as structured by hierarchies that must be preserved at all costs for the society to continue as it is, since those who hold power seek to maintain their control. The perpetuation of white settler values and power depends upon the economically dominant maintaining control of national history and suppressing the secrets that contradict their narratives. Secrets of Walden Rising argues that this dominant view is an exhausted narrative of empire, its power aligned with violence and its legitimacy discredited by unresolved moral dilemmas, and that the residual effects of these conflicts require resolutions rather than effacement from national stories. The novel represents the community's refusal of correction and transition, as embracing reconciliation and compensation is unthinkable; a new negotiation with landscape, meaning and value seems beyond imagining; and patriarchal modes of social interaction and economics predominate, along 
with competitive rather than cooperative social practices. In these storylines then, Secrets of Walden Rising is a critical dystopia because it intends 'to suggest causes rather than merely reveal symptoms' (Penley, cited in Baccolini and Moylan 2003,p.3). Early in the storyline Brendan explicitly asserts that Walden's and Jacks Marsh's 'troll' or 'bird, or ghost or spirit', is real and that its influence continues. In the closure Brendan declares that his attempt at 'the dehaunting of Walden' (p.88) is unsuccessful (p.167). Indeed, while the 'bird still felt dark and dangerous' as it sits atop the Walden hotel (p.167), Brendan now realises that the 'real monster had nothing to do with the bird' (p.167): responsibility lies in human hands. The novel validates the significance of historical narratives because, whether they are oral or written, they represent much more than merely 'bluff and myth' (p.55). Secrets of Walden Rising offers a critique of Australian white settler narratives that express only utopian 'social dreamings' of the nation, and contests their claims to 'salvation' and to 'rural innocence' (White 1981, pp.34-6).

\section{NOTE}

1. The drowning of Australian towns such as Adaminaby beneath new dam waters became a part of the dam-building program that fired the national imagination in the immediate post-war decades.

\section{REFERENCES}

Baccolini, Raffaella (2003) 'Memory and historical reconciliation' in Dark Horizons: Science Fiction and the Dystopian Imagination. London, Routledge, pp.113-34.

Baccolini, Raffaella and Moylan, Tom (eds) (2003) Dark Horizons: Science Fiction and the Dystopian Imagination. London, Routledge.

Baillie, Allan (1996) Secrets of Walden Rising. Ringwood, Vic, Puffin Books Australia.

Blainey, Geoffrey (1991) Eye on Australia: Essays and Speeches of Geoffrey Blainey. Melbourne, Schwartz and Wilkinson.

Cameron, Kate; Lawless, Jennifer and Young, Carmel (2002) Investigating Australian
History in the Twentieth Century. South Melbourne, Nelson.

Curthoys, Ann (1997) 'History \& identity', in W. Hudson \& G. Bolton (eds) Creating Australia: Changing Australian History. St Leonards, Allen \& Unwin, pp.23-38.

Fernandez, M. J. (2001) 'Multiculturalism and social values in Australian fiction: Allan Baillie's Secrets of Walden Rising and Melina Marchetta's Looking for Alibrandi', Papers: Explorations into Children's Literature 11, 3, 39-46.

Macintyre, Stuart (1999) A Concise History of Australia. Cambridge, Cambridge University Press.

Moylan, Tom (1986) Demand the Impossible: Science Fiction and the Utopian Imagination. London and New York, Methuen.

Ruppert, Peter (1986) Reader in a Strange Land: The Activity of Reading Literary Utopias. Athens and London, The University of Georgia Press.

Sambell, Kay (2003) 'Presenting the case for social change: The creative dilemma for dystopian children's literature' in C. Hintz and E. Ostrey (eds) Utopian and Dystopian Writing for Children and Young Adults. New York and London, Routledge, pp.163-178.

Sargent, Lyman Tower (1994) 'The three faces of utopianism revisited', Utopian Studies 5, 1: $1-37$.

Sargent, Lyman Tower (2001) 'Utopianism and the creation of New Zealand national identity', Utopian Studies 12, 1: 1-15.

Sargent, Lyman Tower (2003) 'Afterword' in C. Hintz and E. Ostrey (eds) Utopian and Dystopian Writing for Children and Young Adults. New York and London, Routledge, pp.232-4. 
Stephens, John (1999) 'Continuity, fissure or dysfunction? From settler society to multicultural society in Australian fiction', in R. McGillis (ed), Voices of the Other: Colonial and Postcolonial Children's Literature. New York, Garland, pp.48-62.

Thoreau, David Henry (1934) [1854] Walden, or Life in the Woods. Great Britain, Blackie \& Sons.

Wegner, Philip E. (2002) Imaginary Communities: Utopia, the Nation and the Spatial Histories of Modernity. Berkeley, University of California Press.

White, Richard (1981) Inventing Australia: Images and Identity 1688-1980. St Leonards, Allen \& Unwin.

White, Richard (1997) 'Inventing Australia revisited', in W. Hudson \& G. Bolton (eds) Creating Australia: Changing Australian History. St Leonards, Allen \& Unwin, pp.1222.

\section{BIOGRAPHICAL NOTE}

Beverley Pennell teaches English Curriculum Studies and Children's Literature in the School of Teacher Education at Charles Sturt University. 